\title{
English Language Textbooks and Portrayal of Culture: A content analysis
}

\author{
Ruzai Syarilili Aiyu Abd Rashid ${ }^{1,}$, Engku Haliza Engku Ibrahim \\ ${ }^{1}$ English Language Division, The Centre for Languages and Pre-University Academic Development \\ (CELPAD), International Islamic University Malaysia, 53100, Jalan Gombak, Kuala \\ Lumpur,Malaysia
}

\begin{abstract}
Research has shown that there is a need to use materials that are cultural sensitive and context-appropriate in the EFL classroom. It is imperative that teaching materials match with the goals, objectives and philosophy of the programme. This is to ensure that the materials are congruent with the learners' attitudes, religious beliefs and preferences. Thus, this study aims to find out if there were materials that are not in harmony with Islam. The sampling of this study was taken from 5 textbooks that were being used in an intensive English course. The findings from this study showed that in general the contents of the ELT textbooks could be categorised into three categories of neutral, positive and negative. Additionally, it was also discovered that these themes fall under community knowledge, beliefs and values of the western culture in Byram's (1993) cultural content checklist. This study has strong implications for the use of ready-made textbooks in the EFL context.
\end{abstract}

\section{Introduction}

Many researchers have highlighted that textbooks play an important role in teaching and learning, especially in foreign language classroom. It has been emphasised by Hatoss [26] the importance of culture teaching through language learning that without textbooks, English teachers would find it difficult to teach a cultural content to their students as textbooks supply this need without transporting the students to the native speakers' country. "The presence of cultural content in course books is also important for the development of students' intercultural communicative competence" [53]. Today there is a plethora of commercially available textbooks in the market, thus the growing need to determine whether the teacher or the decision maker has made the right choice concerning the right textbook for the right purpose. As Anjaneyulu [9] affirmed, "the analysis of the textbook would yield insights as to its suitability... It was therefore important to examine whether it corresponded to the learners needs of the particular situation" (p.181).

Wright [55] who studied the factors shaping the attitudes of secondary education learners in Great Britain towards French, found that textbooks are viewed by learners of languages as having a significant influence on their attitudes towards the target culture and

\footnotetext{
*Corresponding author: ruzai_syarilili@iium.edu.my
} 
that there is a significant positive correlation between this influence and the attitudes of many pupils. Additionally, Yamada [57] stated that a textbook is not merely a commercially available reference book which is used in a language teaching programme, it also serves as an important means to deliver political and ideological orientation. She further pointed out that "textbooks can be understood and examined as curricular materials, which project images of society and culture. They reflect historical, social, cultural and socio-cultural, economic and political contexts" (p. 20). Dellinger [16] too asserted that language is a type of social practice used for representation and signification. Texts, including textbooks, are written by socially situated persons. Thus, textbook descriptions can be examined as a social product. In other words, textbooks determine not only material conditions for teaching and learning but also define what elite or legitimate culture is passed on [10]. Apple and Christian-Smith too advocate that a textbook signifies a "particular constructions of reality, particular ways of selecting and organizing that universe of possible knowledge" (1991, p.3).

The constantly changing landscape of higher education has compelled the teaching and learning of English to be culturally sensitive to the context in which the language is taught and used (Kachru, [30]; Prodromou, [38]; Fawwaz and Oqlah, [19]; Ratnawati, [41]; Phillipson, [37]; Al-Attas, [4]; Pennycook, [36]; Canagarajah, [12]; Cardona, [13]; Yamada, [57] and Ainol and Isarji, [3]) This is especially true after the 9/11 tragedy. The teaching and learning of English began to undergo a robust push for the utilisation of teaching materials that meet the needs of learners, institutions, and industry. It necessitates ELT materials and learning outcomes to be well-matched. Despite the realisation of the importance of meeting the needs of ESL learners, institutions, and industry, it is extremely difficult for teaching materials to be socio-culturally neutral because it has to express a social order and value system, implicitly or explicitly [43] With the absence of proper guidance, the tasks could turn out to be complicated in terms of deciding whose value system or social order needs to be incorporated.

On this account, there is an urgent need to study ELT materials from socio-cultural perspectives and its appropriateness to Muslim learners to ensure that the materials complement learners' needs and the vision and mission of the institution.

Literature review: The literature on second language teaching and learning and ELT materials have addressed the need for both learners and teachers to be aware of the dynamic interplay of language, thought and action and the macro and micro cultures on ELT theory and practices. Many studies have been done on socio-cultural perspectives in second language learning. These include the works of Haja Mohideen [22,23,24], Casewit [14], Shamimah (2008), Mojgan Majdzadeh Tabatabaei [31], Mohamed S. Haded [33], Abdullah [2], Yadullah [56], Ratnawati [41,42], Tariq [52], Hyde [28], Fawwaz and Oqlah [19], Ali Ahmed [6], Dahiru [15], Mohamed Ismail [32], Grace [21], Qiang and Wolf [40], Sohail and Pennycook [36], Mohammad Shafi [34], Farzad [18], Pennycook [36], Sami [44], Ainol and Isarji [3], Isarji and Mohd. Feham (2000). Alghamdi and El-Hassan [5] emphasised specifically that "English-language teaching must be responsive to the local culture and realities and must be driven by local needs" (p. 1).

Casewit [14] for example, stated that in developing appropriate materials for learners in Muslim societies, one must look beyond and beneath such superficial confirmation of the social psychological theory of foreign language acquisition. He continues that multicultural TEFL materials could be prepared in such a way as to promote more favourable attitudes and stronger motivation on the part of learners in Muslim societies.

Similarly, Haja Mohideen [23] articulated that language teaching and learning materials need to include a section on offensive expressions to warn users against their usage because English today is not used exclusively by native speakers of English and there is a vast 
number of English as second language speakers who have to use the language but need to know that the target language is appropriate to their religious and cultural values.

Washima et al. [54] highlighted the need to actively promote materials related to the home culture of the learners. This is an effort to minimise the negative effect of ELT materials that could include unwelcome and contradictory values. With the incorporation of local cultures, it encourages both students and teachers to be aware of potential conflicts, to discuss and to critically reflect on how they might respond appropriately.

In selecting reading materials, teachers of Muslim learners need to exercise discretion in the choice of reading texts. In those classes where the learners have a reasonable degree of maturity, the teacher will need to develop the skill of critical reading with particular reference to how easily the unsuspecting reader can be misled into accepting values and norms which are incongruous with the Islamic way of life.

More recently, Alshammari [7] argued that "the existing ESL content lack[s] the diverse nature of English of today and conflict[s] with the Islamic discourses and values" (p. 369). Similarly, Ahmar Mahboob and Tariq Elyas [8] argued that historically, English in Saudi Arabia has been nativised to reflect local cultural practices.

Even though Casewit [14], Washima et al. [54], Haja Mohideen [23] Sugirin et al. [48], Abbas [1], Hermawan [27], Dweikat and Shbeitah [17], Syahri and Susanti [49] and many others have provided critical appraisal of ELT materials in L2 language teaching and learning, there is a need to include empirical evidence based on data collected from ELT materials. More importantly, there is a lack of empirical evidence on the analysis of the content of ELT textbooks which are considered culturally inappropriate to Muslim learners. Considering this inadequacy and in view of the fact that learners are the most important clients of an education institution, it is imperative to study this concern systematically to ensure that the needs of the learners and the institution are accurately met.

The main purpose of the study is to analyze the socio-cultural and religious content of ELT textbooks used in the English Language Programme at the International Islamic University Malaysia. Based on a content analysis, this study also seeks to find out how the materials were being portrayed according to an adaptation of Byram's (1993) Cultural Content Checklist with specific reference to neutral, positive and negative contents.

Specifically, this research will address the questions below:

1. Are there contents that relate to Islam or Muslims in the textbooks?

2. How are the contents portrayed?

\section{Material and Methods}

Data for this study was collected through three major steps; document search, conceptual content analysis and content categorisation based on an adaptation of Byram's (1993) cultural content checklist.

5 textbooks were analysed for the purpose of this study.

1. Interactions 1: Listening and Speaking (T1)

2. Interactions 2: Listening and Speaking (T2)

3. Interactions 2-Reading (T3)

4. Consider the Issue: Listening and Critical Thinking Skills 3rd Ed. (T4)

5. Engaging Writing-Paragraphs and Essays. (T5)

The first step in the data analysis was deciding which data would be analysed throughout the study; which in this case, the chosen textbooks. The concepts covered were the cultural elements of western culture which relate to Islam and the Muslims. At the same time the researcher investigated whether there were western culture elements that were not in 
harmony with Islam. The selected textbooks were also evaluated to find out how Islam and Muslims were portrayed and depicted.

The content analysis applied in this study was utilised as a method of inquiry to explore the cultural content focusing on the different features of western culture which is not in harmony with Islam. References to cultural content of Islam and the Muslim culture mentioned in the textbooks were also identified throughout the materials and were extracted word for word and then coded according to the four elements of Byram's (1993) cultural content checklist as listed below:

- belief and behaviour

- socialisation and life cycle

- stereotypes and national identity

- social and political institution

\section{Results}

Content analysis of the 5 textbooks chosen could be summarised as:

- T1:1 neutral cultural content

- T2:2 neutral cultural contents and 1 positive cultural content.

- T3; 11 neutral cultural contents and 6 negative cultural contents.

- T4: no positive, neutral or negative contents were found

- T5: 2 negative cultural contents

In total there were 23 contents identified, with 14 neutral cultural contents, 1 positive cultural content and 8 negative cultural contents.

Neutral Contents: Based on the analysis, there were thirteen contents that had a neutral portrayal of Islam and Muslims. Some examples are listed below:

- Nabil and the pet: cat.

- Hip-hop in Istanbul.

- Water.

- Islamic Wedding - Bedouin and Henna.

- Bedouin Culture- Henna.

- Mehndi-Islamic cultures.

- United Arab Emirate-unmarried Emeriti men to marry Emeriti women.

- Churches, mosques and palace-structures.

- Arabesques- exquisite design.

- Mosques-Islamic religious worship

- Christianity- religion- Islam.

- Spread of Islam to the East.

- The Middle east-Reality TV show-The Big Brother.

- Banking in the United Arab Emirate.

According to Byram's [11] cultural content checklist, 5 relates to belief and behaviour, another 5 to socialisation and life cycles, 3 to stereotypes and national identity and only one relates to social and political institution.

Positive Contents: There was one positive portrayal of Islam and Muslims found in T2 under the category of stereotypes and national identity. The content was regarding the numeral symbol. According to Byram's [11] cultural content checklist, this falls under stereotypes and national identity.

Negative Contents: Based on the analysis, it was found that there are seven contents that had negative portrayals of Islam and Muslims. Three could be categorised under Byram's [11] category of belief and behaviour, four under socialisation and life cycles and the last 
remaining one under the category of social and political institution. The following examples can be found:

- Islam and Buddhist Art.

- Term: Holy Place.

- $\quad$ Emeriti Wedding.

- Bedouin wedding involves money.

- Emeriti wedding are too lavish.

- Kamal Ataturk.

- Arab's Hospitality.

- The Quran and Hadith

Under Byram's [11] cultural content checklist, these contents relate to belief and behaviour (3), socialisation and life cycles (4) and one to Social and political institution.

\section{Discussions}

The findings of this study support Risager's [43] contention that it is extremely difficult for teaching materials to be socio-culturally neutral because they have to express a social order and value system, implicitly or explicitly. One of the significant findings which emerged from this study is that the contents of the five textbooks seem to portray the social order and value system of the Judeo-Christian. However, it is interesting to note that while the JudeoChristian social order and value system were being portrayed positively, contents related to Islam and Muslims were presented in a negative manner.

In view of the fact that these textbooks are intended for an international audience, it can be assumed that the writers not only had very limited knowledge of Islam and the Muslim culture, but also projected a negative representation of Islam and Muslims. As a result of the negative representation, Muslim learners might feel frustrated or demotivated in their effort to acquire English. A prolonged exposure to negative representations of Islam and Muslims in ELT textbooks, without proper guidance of experienced teachers, may corrode their worldview and Aqidah.

The study shows that 23 contents mentioned Islam and Muslims. Of the 23 contents, $69.5 \%$ were presented in a neutral way; and $30.4 \%$ were presented in a negative manner. It is assumed that this is done unintentionally due to a lack of understanding of different cultural values.

The findings of this research support the assumption that students' motivation may be negatively affected if the materials that they are dealing with are offensive or are not in harmony with their personal worldview. Similarly, teachers may be put in a difficult situation if students strongly voice their objection when these materials are used in the classroom. These findings are in line with Dweikat and Shbeitah's content analysis [17] where they too found that:

the most frequent cultural values were related the American culture which indicated an obvious bias towards the foreign cultural values in general and the American cultural values in particular at the expense of the Arab-Islamic culture as no unit talked about Arabs or Muslims except the mentioning of the word "Arab" which was mentioned only once in the textbook and in a way that even displeases the Arabs. (p.564)

It is also important to realise that if the content relates to universal values like honesty, accountability, social justice, beauty and marriage; the author has to use extreme caution because the comparison that is made in the textbooks is substantial when two cultures are compared with each other. For example, in T5, there are short articles that talk about celebrations in different countries. An article about Fiji presents a celebration as follows; 
Awards are presented to young people for the annual essay competition, and there is a singing contest between church choirs....sometimes winners playfully teases the losers, but there is no serious competition. After the games, players stay to chat with their friends.

Finally, at home a big celebration is underway. Friends and, relatives arrive early to help make palusami-a mixture of chicken, onion and tomato, wrapped in a taro leaf and cooked in coconut milk. The head of the household makes the traditional drink, yaqona, in a large bowl and offers it to the guest in coconut shells. After the yaqona drinking, everyone eats palusami, rice and salad. Fiji Day is our most popular celebration because it incorporates all the things Fijians love most: our national heritage, sports, food and drink, and socializing with family and friends. (p.84)

The portrayal ends in a positive manner. However, the following is used to describe a celebration in Islamic culture;

Another important aspect of Arab culture is hospitality. In Arab countries from Morocco to Iraq, visitors are very warmly welcomed. Relatives, friends, and even strangers are always offered coffee or tea and perhaps some bread or sweets, and if they happen to arrive at mealtime, they are urged to stay and eat. Guests cannot refuse these offers without offending their host. This tradition of hospitality dates back thousands of years. To survive in the desert, nomadic tribesman had to depend on one another, so it became a matter of honour to give and receive hospitality. The Quran and the books known as the Hadith have helped preserve this tradition of hospitality by urging people to practice kindness. But the holy books do not say that kindness and hospitality must be given without limit. Guest must know when to leave, and hospitality must be returned. Hospitality can strengthen the bonds between the members of society only when its rules are followed well. (p.98)

Quite often it might seem as if the depiction of a certain culture is neutral and harmless. However, upon scrutiny, we will see that they are often suggestive in the sense that one culture is cast in positive light while another is depicted negatively. Whereas the presentation of some cultures or regions shows both the positive and the negative sides and is therefore seen as neutral, for other cultures or countries only the good side is presented.

In general, the findings of this study suggest that the evaluated textbooks are loaded with features of the western culture, which affirms Risager's [43] observation that it is rather challenging for ELT materials to be socio-culturally neutral. In the context of this study, it is at the expense of Islam and Muslims. To a certain extent, the findings are coherent with those of Shatawani [46] that there is a clear religious and cultural bias in ELT materials. For example, when the authors make reference to the concept of water (in T2), they make an assumption that both Muslims and Christians have the same perception of water. This could stem from the publisher's lack of awareness of the way water is used as prescribed by the teachings of Islam.

The analysis of the textbooks revealed that there is a noticeable partiality towards foreign cultural values in general and this is at the expense of the Islamic culture.

\section{Conclusion}

There were contents that relate to Muslims and Islam in the textbooks chosen for this research. In term of Byram's [11] cultural content checklist, a majority of the contents that are related to Islam and Muslims are related to the category of socialisation and life cycles.

It is recommended that publishers consult experts on the cultures depicted in their textbooks so that they can be suitable and do not come across as offensive to certain groups of 
readers. Another option that these particular publishers should consider, and many today have done so, is to publish local editions of their textbooks in order to make the contents more culturally responsive to students' needs.

\section{References}

1. Abbas, I., Palestinian and global cultural dimensions in English for Palestine Textbooks for Grades 11 and 12. Journal of Al-Quds Open University for Research and Studies, pp. 69-91, (2011)

2. Abdullah Hamad, The Problem of Culture in Language Teaching. Muslim Education Quarterly. Vol. 16. No.2. The Islamic Academy, Cambridge. UK, (1999)

3. Ainol Madziah, Z and Isarji, S., November. Islamization of English Language Teaching. Proceedings of the 2nd International Conference on Language, Education and Diversity, 2007, University of Waikato, Hamilton, New Zealand, (2007)

4. Al-Attas, S.M.N, Islam and Secularism. Kuala Lumpur, Malaysia. Angkatan Belia Islam Malaysia, (1978)

5. Alghamdi, A. K., and El-Hassan, W.S., Multiliteracies and the Pedagogy of Empowerment: The Perspective of Saudi Female Students. The Journal of Teaching English for Specific and Academic Purposes, pp. 417-434, (2016)

6. Ali Ahmed Hussein., ESP Materials Development: the Case of Islamic ESP. English and Islam: Creative Encounters. p. 4, (1996)

7. Alshammari, A. K., Developing the English Curriculum in the Kingdom of Saudi Arabia: Possibilities and Challenges. Arab World English Journal, p. 369, (2015)

8. Ammar Mahboob and Tariq Elyas,. English in the Kingdom of Saudi Arabia. World Englishes, p. 138, (2014)

9. Anjaneyulu, T. A critical analysis of the English language textbooks in. ELT Research Journal, pp. 181-200, (2014)

10. Apple, M. and Linda Christian-Smith, eds,. The Politics of the Textbook. London. Routledge, (1991)

11. Byram, M,. Language and Culture: The Need for Integration. In M. Byram (ed.), Germany, Its representation in textbook for teaching German in Great Britain Germany, Frankfurt am Main: Diesterweg, pp. 3-16, (1993)

12. Canagarajah, S., Resisting Linguistics Imperialism in English Teaching. Oxford, England: Oxford University Press, (1999)

13. Cardona, S. M., Teaching English the Puerto Rican way: developing ESL materials that mirror the source culture for the Puerto Rican elementary English classroom. Puerto Rico: University of Puerto Rico, (2008)

14. Casewit, S. D, Teaching English as a foreign language in Muslim Countries. Muslim Education Quarterly 2(2), Cambridge: UK, (1985)

15. Dahiru Muhammad Argungu,. English, Muslims and Islamisation: Between Needs and Deeds. English and Islam: Creative Encounters. p. 9, (1996)

16. Dellinger, B,. Critical Discourse Analysis. Retrieved on April 21, 2008 http://users.utu.fie.bredelli/cda.html, (1995)

17. Dweikat, K. A., and Shbeitah, G,. Investigating the Cultural Values in EFL Textbooks A Case Study of NorthStar Intermediate Textbook. The Islamic University of Educational and Psychological Studies Journal, pp. 564-589, (2013) 
18. Farzad Sharifian. The Impact of Macro-cultures and Micro-cultures on ELT Theory and Practice. Retrieved May 3, 2008.http://www.ecu.edu.au/ses/research/CALLR/onlinejournal/1999/Sharifian99. htm, (1999)

19. Fawwaz al-Abed al-Haq and Oqlah Smadi., Spread of English and Westernization in Saudi Arabia. World Englishes. Vol 15 No 3, p. 6, (1996)

20. Fitzpatrick, M, Engaging Writing-Paragraphs and Essays. Pearson Longman, (2005)

21. Grace Ebunlola Adamo., Globalisation, Terrorism and the English Language in Nigeria. English Today 84, Vol.21, No Cambridge University Press, (2005)

22. Haja Mohideen M.A., Second Language Teaching and Learning from an Islamic Perspective. Muslim Education Quarterly Vol.16.No.2 the Islamic Academy. Cambridge .U.K, (1999)

23. Haja Mohideen M.A., 'Mind Your Language': An Islamic Perspective. Muslim Education Quarterly Vol.17.No.2. The Islamic Academy. Cambridge .U.K, (2000)

24. Haja Mohideen M.A., Islamic Correctness in Language Use. Muslim Education Quarterly Vol.19. No.1. the Islamic Academy. Cambridge .U.K, (2001)

25. Hartmann, P and Kirn, E,. Interactions 2-Reading. McGraw-Hill, (2007)

26. Hatoss, A., A model for evaluating textbooks as mediators of culture. Babel Vol. 39 No. 2 pp. 25-32, retrieved 3rd December.2008.http://eprints.usq.edu.au/archive/00001137/02/Hatoss.pdf, (2004)

27. Hermawan, B., Traces of cultures in English textbooks for primary education. Indonesian Journal of Applied Linguistics, (2012)

28. Hyde, M., The Teaching of English in Morocco: The Place of Culture. ELT Journal Vol 48. No 4. Oxford University Press, (1994)

29. Isarji, S and Mohd. Feham., Islamic English and English Language Teaching (ELT) Materials. Proceedings of the International Conference on Islamization of Human Sciences, the International Islamic University Malaysia, Kuala Lumpur, (2000)

30. Kachru, B.B., The speaking tree: A medium of plural canons. In Georgetown Round Table in Languages and Linguistics (GURT). Washington, D.C.: Georgetown University Press, (1994)

31. Majdzadeh Tabatabaei, M., National identity and civic values in the pre-revolution and post-revolution English as a foreign language textbook in Iran. Ph.D. dissertation, Loyola University Chicago, United States -- Illinois. Retrieved June 17, 2008, from Dissertations and Theses: Full Text database. (Publication No. AAT 3212975) (2006)

32. Mohamed Ismail A.S., An Approach to the Islamization of the Teaching of English: Teaching Islamic Literature in the English Language Classroom. Muslim Education Quarterly Vol.16. No.2. p. 5, (1999)

33. Mohamed S.H., Focus on The Muslim Learner of English: The Communicative Approach and the Teacher's Role. Muslim Education Quarterly. Vol 16.No.1 1998 the Islamic Academy, Cambridge. U.K, (1998)

34. Mohamad Shafi,. Teaching of English as a foreign language: The Islamic Approach. Muslim Education Quarterly Vol. 1. No. 1. p. 5, (1983)

35. Numrich, C., Consider The Issue. Listening and Critical Thinking Skills (3rd ed.) Longman. NY, (2003)

36. Pennycook, A., English and Islam. Extracted from The Cultural Politics of English as an International Language. Retrieved on May 3 2008.http://www.tesolislamia.org/articles/pennycook.pdf, (1994) 
37. Phillipson, R.H.L., Linguistic Imperialism. Oxford: Oxford University Press, (1992)

38. Prodromou, L., ELTJ correspondence. ELTJ, Vol. 52 no.3. pp. 266-267, (1998)

39. Prodromou, L., The good language teacher. In Teacher development: Making the right moves, selected articles from the English Teaching Forum 1989-1993, ed. T. Kral. Washington, DC: U.S. Information Agency, (1994)

40. Qiang, N and Wolff, M., Is EFL a Modern Trojan Horse? English Today Vol. 21, Issue 4 Cambridge University Press.UK, (2005)

41. Ratnawati, M.A,. The Cultural Implications of Teaching English as a Second or Foreign Language. Muslim Education Quarterly. Vol 14, No 4. The Islamic Academy, Cambridge, U.K, (1997)

42. Ratnawati M.A., English and Islam: A Clash of Civilization. Journal of Language, Identity and Education Vol.4.No.2, (2005)

43. Risager, K., Cultural references in European textbooks: An evaluation of recent tendencies. In: Buttjes, D.; Byram, M. (eds.), Mediating languages and cultures. Clevedon, UK, Multilingual Matters, (1990)

44. Sami Samra., The Cultural Factor in L2 Acquisition: Between Theory and Application. Proceedings of the Association of Professor of English and Translation at Arab Universities First International Conference, Jordan University. Retrieved May $\quad 15 \quad 2008$. http://www.ndu.edu.lb/rfr.htm?http://www.ndu.edu.lb/academics/palma/20010701 /CulturalFactorL2.htm, (2000)

45. Shamimah, M., Introducing Islamic Elements in English Language Teaching. Proceedings of the International Language Conference 2008, International Islamic University Malaysia, (2008)

46. Shatanawi, M., The Cultural Dimension in TEFL: A Case Study of the Cutting Edge Series, Unpublished Ph.D. Dissertation. Amman Arab University for Graduate Studies. Jordan, (2005)

47. Sohail Karmani and Pennycook, A., Islam, English and 9/11. Journal of Language, identity and Education. Vol 4.No.2. pp 157-172, (2005)

48. Sugirin, Sudartini, S., Suciati, and Nurhayati, L,. A study on cultural integration in the English textbooks for junior high schools. LITERA, pp. 235-246, (2011)

49. Syahri, I. and Susanti, R. An Analysis of Local and Target Culture Integration in the English Textbooks for Senior High. Journal of Education and Human Development, pp. 97-102.

50. Tanka, J and Most, P., Interactions 1, Listening and Speaking. McGraw-Hill, (2007)

51. Tanka, J and Baker, L. R., Interactions 2, Listening and Speaking. McGraw-Hill, (2007)

52. Tariq Rahman, The Muslim Response to English in South Asia: With Special Reference to Inequality, Intolerance and Militancy in Pakistan. Journal of language, Identity and Education. Vol 4 No 2 p. 9, (2005)

53. Teo, A. and Kaewsakul, W., Cultural Contents in Fundamental English Coursebooks. NIDA Journal of Language and Communication, pp.1-17, (2016)

54. Washima Che Dan, Harshita Aini Haroon and Naysmith, J., English and Islam in Malaysia: Resolving the Tension. World Englishes. Vol. 15.No.2. p. 6, (1996)

55. Wright. M., Influences on Learner Attitudes towards Foreign Language and Culture. Educational Research Vol. 41. No. 2. p. 12, (1999)

56. Yadullah Kazmi., The Hidden Political Agenda of Teaching English as an International Language. Muslim Education Quarterly. Vol.15. No. 1. The Islamic Academy, Cambridge. UK, (1997) 
57. Yamada, M., The representation of race and ethnic relations in Japanese junior high school English language textbooks from 1987 to 2002. Ph.D. dissertation, Western Michigan University, United States -- Michigan. Retrieved June 17, 2008, from Dissertations and Theses: Full Text database. (Publication No. AAT 3221660), (2006)

\section{Tables}

Table 1: The portrayal of Islam and Muslims in English language textbooks.

\begin{tabular}{|l|l|l|l|l|}
\hline & Neutral & Positive & Negative & Total \\
\hline Interactions 1: Listening/ Speaking & 1 & 0 & 0 & 1 \\
\hline Interactions 2: Listening/Speaking & 2 & 1 & 0 & 3 \\
\hline Interactions 2-Reading & 11 & 0 & 6 & 17 \\
\hline $\begin{array}{l}\text { Engaging Writing: Paragraphs and } \\
\text { Essays }\end{array}$ & 0 & 0 & 2 & 2 \\
\hline $\begin{array}{l}\text { Consider the Issue: Listening and } \\
\text { Critical Thinking Skills 3rd ed. }\end{array}$ & 0 & 0 & 0 & 0 \\
\hline TOTAL & 14 & 1 & 8 & 23 \\
\hline
\end{tabular}

Table 2: The category based on Byram's (1993) cultural content checklist.

\begin{tabular}{|l|l|l|}
\hline No. & Category & Contents \\
\hline 1. & Belief and behaviour & 8 \\
\hline 2. & Socialisation and life cycles & 9 \\
\hline 3. & Stereotypes and national identity & 4 \\
\hline 4. & Social and political institution & 2 \\
\hline & Total & 23 \\
\hline
\end{tabular}

Table 3: The portrayal of Islam and Muslims as Neutral in English language textbooks.

\begin{tabular}{|l|l|l|l|}
\hline $\begin{array}{l}\text { No } \\
.\end{array}$ & Content & Category & Textbook \\
\hline 1. & Nabil and the pet: cat & Belief and behaviour & $\begin{array}{l}\text { Interactions 1: Listening } \\
\text { Speaking }\end{array}$ \\
\hline 2. & Hip-hop in Istanbul & Belief and behaviour & $\begin{array}{l}\text { Interactions 2: } \\
\text { Listening/Speaking }\end{array}$ \\
\hline 3. & Water & Belief and behaviour & $\begin{array}{l}\text { Interactions 2: } \\
\text { Listening/Speaking }\end{array}$ \\
\hline 4. & $\begin{array}{l}\text { Islamic Wedding - Bedouin } \\
\text { and Henna }\end{array}$ & $\begin{array}{l}\text { Socialisation and life } \\
\text { cycles }\end{array}$ & Interactions 2-Reading \\
\hline 5. & Bedouin Culture- Henna & $\begin{array}{l}\text { Socialisation and life } \\
\text { cycles }\end{array}$ & Interactions 2-Reading \\
\hline 6. & Mehndi-Islamic cultures & $\begin{array}{l}\text { Socialisation and life } \\
\text { cycles }\end{array}$ & Interactions 2-Reading \\
\hline
\end{tabular}




\begin{tabular}{|c|l|l|l|}
\hline 7. & $\begin{array}{l}\text { United Arab Emirate- } \\
\text { unmarried Emeriti men to } \\
\text { marry Emeriti women }\end{array}$ & $\begin{array}{l}\text { Socialisation and life } \\
\text { cycles }\end{array}$ & Interactions 2-Reading \\
\hline 8. & $\begin{array}{l}\text { Churches, mosques and } \\
\text { palace-structures }\end{array}$ & $\begin{array}{l}\text { Stereotypes and } \\
\text { national identity }\end{array}$ & Interactions 2-Reading \\
\hline 9. & $\begin{array}{l}\text { Arabesques-exquisite } \\
\text { design }\end{array}$ & $\begin{array}{l}\text { Stereotypes and } \\
\text { national identity }\end{array}$ & Interactions 2-Reading \\
\hline 10. & $\begin{array}{l}\text { Mosques-Islamic religious } \\
\text { worship }\end{array}$ & $\begin{array}{l}\text { Stereotypes and } \\
\text { national identity }\end{array}$ & Interactions 2-Reading \\
\hline 11. & Christianity- religion- Islam & Belief and behaviour & Interactions 2-Reading \\
\hline 12. & Spread of Islam to the East & Belief and behaviour & Interactions 2-Reading \\
\hline 13. & $\begin{array}{l}\text { The Middle east-Reality } \\
\text { TV show-The Big Brother }\end{array}$ & $\begin{array}{l}\text { Socialisation and life } \\
\text { cycles }\end{array}$ & Interactions 2-Reading \\
\hline 14. & $\begin{array}{l}\text { Banking in The United } \\
\text { Arab Emirate }\end{array}$ & $\begin{array}{l}\text { Social and political } \\
\text { institution }\end{array}$ & Interactions 2-Reading \\
\hline
\end{tabular}

Table 4: The category for Neutral contents based on Byram's (1993) cultural content checklist

\begin{tabular}{|l|l|l|}
\hline No. & Category & Contents \\
\hline 1. & Belief and behaviour & 5 \\
\hline 2. & Socialisation and life cycles & 5 \\
\hline 3. & Stereotypes and national identity & 3 \\
\hline 4. & Social and political institution & 1 \\
\hline & Total & 14 \\
\hline
\end{tabular}

Table 5: The portrayal of Islam and Muslims as Positive in English language textbooks.

\begin{tabular}{|l|l|l|l|}
\hline No. & Content & Category & \multicolumn{1}{c|}{ Textbook } \\
\hline 1. & Numeral Symbol & $\begin{array}{l}\text { Stereotypes and national } \\
\text { identity }\end{array}$ & $\begin{array}{l}\text { Interactions 2: } \\
\text { Listening/Speaking }\end{array}$ \\
\hline
\end{tabular}

Table 6: The category for Positive contents based on Byram's (1993) cultural content checklist

\begin{tabular}{|l|l|l|}
\hline No. & Category & Contents \\
\hline 1. & Belief and behaviour & 0 \\
\hline 2. & Socialisation and life cycles & 0 \\
\hline
\end{tabular}




\begin{tabular}{|l|l|l|}
\hline 3. & Stereotypes and national identity & 1 \\
\hline 4. & Social and political institution & 0 \\
\hline & Total & 1 \\
\hline
\end{tabular}

Table 7: The portrayal of Islam and Muslims as Negative in English language textbooks.

\begin{tabular}{|l|l|l|l|}
\hline $\begin{array}{l}\text { No } \\
.\end{array}$ & Content & Category & Textbook \\
\hline 1. & Islam and Buddhist Art & Belief and behaviour & $\begin{array}{l}\text { Interactions 2- } \\
\text { Reading }\end{array}$ \\
\hline 2. & Term: Holy Place & Belief and behaviour & $\begin{array}{l}\text { Interactions 2- } \\
\text { Reading }\end{array}$ \\
\hline 3. & Emeriti Wedding & $\begin{array}{l}\text { Socialisation and life } \\
\text { cycles }\end{array}$ & $\begin{array}{l}\text { Interactions 2- } \\
\text { Reading }\end{array}$ \\
\hline 4. & $\begin{array}{l}\text { Bedouin wedding involves } \\
\text { money }\end{array}$ & $\begin{array}{l}\text { Socialisation and life } \\
\text { cycles }\end{array}$ & $\begin{array}{l}\text { Interactions 2- } \\
\text { Reading }\end{array}$ \\
\hline 5. & $\begin{array}{l}\text { Emeriti wedding are too } \\
\text { lavish }\end{array}$ & $\begin{array}{l}\text { Socialisation and life } \\
\text { cycles }\end{array}$ & $\begin{array}{l}\text { Interactions 2- } \\
\text { Reading }\end{array}$ \\
\hline 6. & Kamal Ataturk & $\begin{array}{l}\text { Social and political } \\
\text { institution }\end{array}$ & $\begin{array}{l}\text { Interactions 2- } \\
\text { Reading }\end{array}$ \\
\hline 7. & Arab's Hospitality & $\begin{array}{l}\text { Socialisation and life } \\
\text { cycles }\end{array}$ & Engaging Writing \\
\hline 8. & The Quran and Hadith & Belief and behaviour & Engaging Writing \\
\hline
\end{tabular}

Table 8: The category for Negative contents based on Byram's (1993) cultural content checklist

\begin{tabular}{|l|l|l|}
\hline No. & Category & Contents \\
\hline 1. & Belief and behaviour & 3 \\
\hline 2. & Socialisation and life cycles & 4 \\
\hline 3. & Stereotypes and national identity & 0 \\
\hline 4. & Social and political institution & 1 \\
\hline & Total & 8 \\
\hline
\end{tabular}

